\title{
EFFECT OF Melanaphis donacis Passerini (HEMIPTERA: APHIDIDAE) ON BIOMASS OF Arundo donax L. (Poaceae)
}

\author{
EFECTO DE Melanaphis donacis Passerini (HEMIPTERA: APHIDIDAE) EN LA \\ BIOMASA DE Arundo donax L. (Poaceae)
}

\author{
Nicole Undurraga ${ }^{1}$, Jaime E. Araya ${ }^{1 *}$, Francisco Zuazúa ${ }^{2}$, and Máximo F. Alonso ${ }^{3}$ \\ ${ }^{1}$ Departamento de Sanidad Vegetal, Facultad de Ciencias Agronómicas, Universidad de Chile, Casilla \\ 1004, Santiago, Chile. \\ ${ }^{2}$ Escuela de Agronomía, Facultad de Ciencias, Universidad Mayor, Camino La Pirámide 5750, \\ Huechuraba, Santiago, Chile. \\ ${ }^{3}$ Instituto de Producción Animal, Facultad de Ciencias Agrarias, Universidad Austral de Chile, Casilla \\ 567, Valdivia, Chile. \\ * Corresponding author E-mail: jaimearaya@yahoo.com
}

\begin{abstract}
Giant reed, Arundo donax (L.), is known for its potential as a bioenergy crop. To evaluate the effect of the aphid Melanaphis donacis (Passerini) on plants growing in the Metropolitan Region of Chile, three treatments with six plots each were compared: imidacloprid, the agricultural detergent TS2035, and an untreated control. Aphid density levels in the untreated control plants averaged 136.27 aphids leaf ${ }^{-1}$ along the growing season, while TS2035 and imidacloprid averaged 8.26 and 0.98 aphids leaf ${ }^{1}$, respectively. The greatest yield of $A$. donax $\left(95.1 \mathrm{t}\right.$ dry matter (DM) ha $\left.{ }^{-1}\right)$ was obtained with the TS2035 detergent, followed by imidacloprid and the untreated control, with values of 88.8 and 84.1 t DM ha ${ }^{-1}$, respectively. However, there were no significant differences $(\mathrm{p} \leq 0.05)$ in DM yields of $A$. donax between treatments. Thus, control of $M$. donacis with insecticides would be unnecessary in bioenergy crops of A. donax in this region.
\end{abstract}

Key words: Detergent TS2035, bioenergy crop, giant reed, Arundo donax, imidacloprid, Mediterranean region.

\section{RESUMEN}

El arundo, Arundo donax (L.) se conoce como cultivo para bioenergía en muchos países. Para evaluar el efecto del áfido Melanaphis donacis (Passerini) en arundo en la Región Metropolitana (Mediterránea) de Chile, se compararon tres tratamientos: imidacloprid, el detergente agrícola TS2035 y un control no tratado. Los niveles de densidad de áfidos en las plantas control no tratadas promediaron 136,27 pulgones hoja ${ }^{-1}$ a lo largo de la temporada de crecimiento, mientras que TS2035 e imidacloprid promediaron 8,26 y 0,98 pulgones hoja ${ }^{-1}$, respectivamente. El mayor rendimiento de A. donax, equivalente a 95,1 t de materia seca (MS) $\mathrm{ha}^{-1}$, se obtuvo con el detergente TS2035, seguido de imidacloprid con 88,8 y el control sin tratar con $84,1 \mathrm{t} \mathrm{MS} \mathrm{ha-}^{-1}$, respectivamente. Sin embargo, no hubo diferencias significativas $(\mathrm{p} \leq 0,05)$ en los rendimientos de MS de $A$. donax entre tratamientos. Por lo tanto, el control de M. donacis con insecticidas sería innecesario en cultivos de $A$. donax para bioenergía.

Palabras clave: Detergente TS2035, cultivo energético, caña gigante, Arundo donax, imidacloprid, Región Mediterránea.

Received: 13 December 2018. $\quad$ Accepted: 17 June 2019. 


\section{INTRODUCTION}

Giant reed, Arundo donax L., a fast growing and high yielding Poaceae, has been highlighted as a potentially important bioenergy crop (Lewandowski et al., 2003; Angelini et al., 2005; 2009; Nassi o Di Nasso et al., 2011) that could satisfy part of the world's energy demands (Mariani et al., 2010), although some fear its invasive weed aggressiveness (e.g. Ahmad et al., 2008; Lambert et al., 2010). Because of its potential for bioenergy, A. donax is being experimentally cultivated in Chile.

Most recent research on $A$. donax grown for biomass has focused almost solely on its potential yield, physiology and the optimal agronomic practices for its cultivation. Little attention has been given to insect populations that can develop on the crop and could become potential pests for the species, in particular aphids the most important pests in herbaceous crops (Blackm,an and Eastop, 2000). However, it is difficult to accurately assess the economic losses caused by aphids, since their density varies greatly throughout the year (Michaud and Sloderbeck, 2005). Thus, year-round studies of aphid population dynamics should be carried out.

The presence of the giant reed aphid, Melanaphis donacis (Passerini), has been reported in wild plants of $A$. donax in the Mediterranean Region of Chile (Nieto-Nafría et al., 2016), but its effect on the biomass production is unknown.

The broad spectrum of neonicotinoid insecticides has a long residual effect on juvenile and adult insects acting by contact and ingestion, and interfere with the nervous stimuli (Bayer CropScience, 2014). The agricultural detergent dissolves the wax layers of the insect's cuticle and breaks cell membranes, which dehydrates and kills aphids; also reduces the superficial tension, allowing water to enter through spiracles and drown insects. It also dislodges individuals from the foliage (Curkovic and Araya, 2004).

This research studied the effect of $M$. donacis on the biomass yield of $A$. donax grown in experimental plots throughout the year under three conditions: an untreated control, a treatment with the insecticide imidacloprid, and a treatment with an agricultural detergent.

\section{MATERIALS AND METHODS}

This study was carried out at the Antumapu Campus and Experimental Station, University of Chile, La Pintana $\left(33^{\circ} 34^{\prime} 8^{\prime \prime}\right.$ S; $70^{\circ} 38^{\prime} 40^{\prime \prime}$ W), Santiago, in eighteen $4 \mathrm{~m}^{2}$ giant reed plots planted at 20,000 plants ha- ${ }^{-1}$, with 3 rows of 5 plants each and a total of 15 plants per plot.
The soil of the plots belongs to the Santiago series, a member of the sandy Mollisol family. It is of alluvial origin, slightly deep and flat topography (0-1\% slope), with little micro relief in a wide fan on both banks of the Maipo river. The effective soil depth varies from 30 to $73 \mathrm{~cm}$. The average annual temperature is $15-16^{\circ} \mathrm{C}$. The soil is well-drained and moderately dry areas occur only occasionally (Casanova et al., 2004).

Rhizomes for planting were obtained from wild $A$. donax plants located at the side of the road to Rinconada de Maipú, next to the Joaquín Olivares area $\left(33^{\circ} 30^{\prime} 0.17^{\prime \prime}\right.$ S, $70^{\circ} 49^{\prime} 12.25^{\prime \prime}$ W). The canes were cut $10 \mathrm{~cm}$ high from the ground and removed to collect the rhizomes down to a $\sim 50 \mathrm{~cm}$ depth, with the least possible damage. Clean rhizomes (without wetting) were taken to the Antumapu Campus, where they were cut and prepared. Those weighing 200-300 g, with at least one sprout, were taken used for planting the plots. The soil of the trial area was plowed once and crumbled twice with a disc plow. The crop was established in October 1, 2012, on ridges separated $1 \mathrm{~m}$ with rhizomes at $0.5 \mathrm{~m}$ in the row, in $4 \mathrm{~m}^{2}$ plots $(20,000$ plants ha-1 $)$. Based on soil and water analyses and the recommendations of Angelini et al. (2005), $50 \mathrm{~g}$ of urea (equivalent to $300 \mathrm{~kg} \mathrm{~N} \mathrm{ha}^{-1}$ ) and $30 \mathrm{~g}$ of triple super phosphate (equivalent to $200 \mathrm{~kg}$ of $\mathrm{P}_{2} \mathrm{O}_{5}$ ha-1) were applied per plant at the establishment of the plots and at mid-season. Glyphosate (Cortador ${ }^{\circledR} 48 \%$ SL) was applied three times during the growing season at $2.5 \mathrm{~L} \mathrm{ha}^{-1}$ for post-emergence control of Poaceae, Cyperaceae and broadleaf weeds. In addition, weeds were hand controlled three to four times a month. Furrow irrigation was carried out twice a week to keep the soil close to field capacity.

The study included three treatments: the application of imidacloprid, the agricultural detergent TS2035 using a hand sprayer (SOLO 1 gal, Santiago, Chile), plus an untreated control. The detergent TS2035 (Pace International) was applied every $\sim 15 \mathrm{~d}$ at $0.5 \% \mathrm{v} / \mathrm{v}$ the first five sprays and at $1.0 \% \mathrm{v} / \mathrm{v}$ the next five sprays. The detergent was sprayed slowly until dripping to ensure good covering. To ensure good residual action, the insecticide imidacloprid (Confidor ${ }^{\circledR}$ $350 \mathrm{SC}$ ) was sprayed twice using $\sim 330 \mathrm{~mL}$ of the corresponding solution per plot. Dosages and spraying dates are presented in Table 1.

Treatments were distributed in a completely randomized experimental design with six replicates. Plots were harvested on June 3, 2013, and the fresh weight of the canes was determined with an electronic crane scale OCS 0.5T. Canes were cut $10 \mathrm{~cm}$ above the ground. To estimate dry matter (DM) yield, three canes of each treatment and replicate were selected at random and dried 
Table 1. Schedule of control treatments against $M$. donacis.

\begin{tabular}{|c|c|c|}
\hline Commercial products & Dosages & Spraying dates \\
\hline Confidor ${ }^{\circledR} 350$ SC & $330 \mathrm{~mL} 4 \mathrm{~m}^{-2}$ & $\begin{array}{l}05 \text { Dec } 2012 \\
05 \text { Mar } 2013\end{array}$ \\
\hline TS2035 & $0.5 \mathrm{~L} \mathrm{pl}^{-1}$ & $\begin{array}{l}\text { 05 Dec } 2012 \\
\text { 17 Jan } 2013 \\
\text { 01 Feb } 2013 \\
\text { 22 Feb } 2013 \\
\text { 05 Mar } 2013 \\
\text { 20 Mar } 2013 \\
\text { 15 Apr } 2013 \\
\text { 09 May } 2013 \\
\text { 24 May } 2013\end{array}$ \\
\hline
\end{tabular}

at $70 \pm 3^{\circ} \mathrm{C}$ for $7-10 \mathrm{~d}$ until constant weight. In each plot, canes plant $\mathrm{t}^{-1}$ and canes $\mathrm{m}^{-2}$ were recorded.

Aphids in each treatment were sampled every $15 \mathrm{~d}$ once they began to colonize the plants, from December 26, 2012 through the harvest. For the counts, 3 plants were randomly chosen from each plot. The $3^{\text {rd }}$ most recent leaf of each plant (later the leaf representative of infestation) was cut, for a total of 18 samplings per treatment. These leaves were taken in individual cold plastic bags to the Crop Entomology Laboratory, Department of Plant Protection, University of Chile, where the aphids on both sides of each leaf were counted under a stereoscopic magnifier (Zeiss Stemi DV4, Fisher Scientific SL - C / Luis L 9, 28031 Madrid, Spain).

Data collected were revised for normality and homoscedasticity. Results were evaluated by an ANOVA and differences among treatments were detected by a post-hoc Tukey test at $5 \%$, using Infostat ${ }^{\circledR}$.

\section{RESULTS}

Yield of A. donax. Mean fresh and dry matter yields obtained in each treatment are presented in Table 2.

Although treatments were not significantly different for yield component's parameters (Table 2 ), treatments with aphid control tended to have higher yields than the untreated control.

Population of M. donacis. Aphid densities in the treatments with TS2035 and imidacloprid were statistically similar after the first spray compared to the untreated control (Table 3). These densities were maintained until harvest, thus both treatments were similarly effective in reducing aphid density.

Means of aphids leaf ${ }^{-1}$ for each treatment from December 2012 through May 2013 are presented in Fig. 1. Mean aphid counts per leaf were significantly different $(p \leq 0.05)$ between treated plots and untreated control plots. While the untreated control reached a mean of 136.27 aphids leaf ${ }^{-1}$ during the growing season, the means of the treatments with TS2035 and imidacloprid were 8.26 and 0.98 aphids leaf ${ }^{-1}$, respectively. Differences between treatments with TS2035 and imidacloprid applications were not significant $(p$ $\leq 0.05)$.

\section{DISCUSSION}

Effect of $M$. donacis populations on yield of A. donax. Results obtained suggest that no significant yield loss of $A$. donax occurred at the aphid density levels reached in the untreated control plots, with a maximum of 242.72 aphids leaf $^{-1}$ at the end of the summer. Thus, the application of products with insecticide effect to control the aphid under the conditions of the trial should not be justified.

Decision making regarding the need for control is generally based on experimental studies investigating about the relationship between the level of infestation and yield loss. The ability to determine this relationship is limited, since the presence of the insect does not always generate damages resulting in economic loss (Fabre et al., 2003).

The applications of insecticides could be justified by the prevention of viral crop diseases. Thus, it is necessary to examine the sanitary risks associated to the production of raw material from A. donax, especially the potential of this plant to be infected with pathogens like Barley Yellow Dwarf Virus (BYDV) and the risk of spreading it to neighboring crops. According to Ingwell et al. (2014), who first reported BYDV-PAV vectored by Rhopalosiphum padi L. in A. donax growing in the USA under controlled conditions, giant 
Table 2. Cane characteristics and fresh and dry matter yields $( \pm \mathrm{SD})$ of $A$. donax under different aphid control methods ( $n=54$ canes).

\begin{tabular}{lccccc}
\hline Treatments & & \multicolumn{4}{c}{ Parameters } \\
& Canes plant $^{-1}$ & ${\text { Canes } \mathbf{~}^{-2}}^{-2}$ & Cane weight, $\mathbf{g}$ & Fresh weight, $\mathbf{~ k ~ m ~}^{-2}$ & Dry matter, $\mathbf{~ k g ~ m}^{-2}$ \\
\hline Imidacloprid & $11.23 \pm 1.30 \mathrm{a}$ & $42.13 \pm 4.90 \mathrm{a}$ & $210.29 \pm 10.03 \mathrm{a}$ & $20.27 \pm 4.25 \mathrm{a}$ & $8.88 \pm 1.86 \mathrm{a}$ \\
TS2035 & $10.67 \pm 1.25 \mathrm{a}$ & $40.00 \pm 4.67 \mathrm{a}$ & $237.34 \pm 12.17 \mathrm{a}$ & $21.72 \pm 4.24 \mathrm{a}$ & $9.51 \pm 1.86 \mathrm{a}$ \\
Untreated & $11.03 \pm 1.36 \mathrm{a}$ & $41.33 \pm 5.08 \mathrm{a}$ & $201.39 \pm 8.90 \mathrm{a}$ & $19.18 \pm 4.34 \mathrm{a}$ & $8.41 \pm 1.90 \mathrm{a}$
\end{tabular}

Different letters in a column indicate significant differences $(\mathrm{p} \leq 0.05)$ in Tukey tests.

Table 3. Density of $M$. donacis leaf ${ }^{-1}$ before and after the first control on December 5, 2012.

\begin{tabular}{lccc}
\hline Means & TS2035 & $\begin{array}{c}\text { Treatments } \\
\text { Imidacloprid }\end{array}$ & Untreated control \\
\hline Pre application & $64.72 \mathrm{a}$ & $68.33 \mathrm{a}$ & $68.77 \mathrm{a}$ \\
Post application & $9.22 \mathrm{~b}$ & $0.11 \mathrm{~b}$ & $67.33 \mathrm{a}$
\end{tabular}

Different letters in a column indicate significant differences $(\mathrm{p} \leq 0.05)$, in Tukey tests.

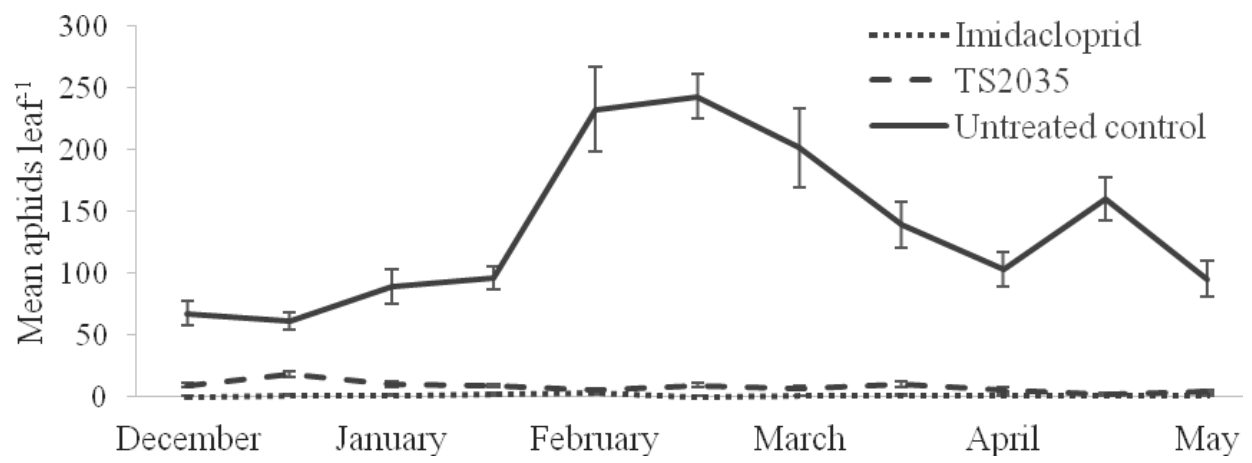

Fig. 1. Means of M. donacis leaf ${ }^{-1}$ in the treatments from December 26, 2012 through harvest on June 3, 2013.

reed would be tolerant to the infection and its production would not be affected. However, more studies are needed to confirm this.

The transmission of BYDV by aphid species has been studied worldwide (e.g., Fabre et al., 2003). Previous studies have evaluated whether A. donax can be a source of BYDV, like the one by Tóth et al. (2011), who found a collection of Italian reed ecotypes and some Hungarian ecotypes free of the virus. On the other hand, Bradshaw et al. (2010) found Sipha flava (Forbes) and Rhopalosiphum maidis (Fitch) on Miscanthus x giganteus in the USA, and noted that both aphids have the potential to damage young plants as they do in other crops, so they could become a problem of economic importance. Ingwell et al. (2014) suggested that R. maidis, common in cereals and forage grasses may inoculate BYDV-PAV, and that growing $A$. donax could influence the ecology and epidemiology of this virus affecting neighboring small grains.

Effectiveness of treatments in the control of $M$. donacis. The two products with insecticide effect evaluated significantly reduced $M$. donacis densities until harvest.

Although imidacloprid was applied only twice, it kept $M$. donacis populations under control throughout the 6-month study, as expected from its mode of action on the nervous system of insects. In general, imidacloprid is effective in suppressing aphids for extended periods (Joshi and Sharma, 2009; El-Naggar et al., 2013). Mizell and Sconyers (1992) found that this neonicotinoid 
insecticide affect some beneficial predators, but Jeschke et al. (2011) estimated that this compound would represent a relatively low risk for non-target organisms and the environment, and it is necessary to promote the development of practices without environmental impacts and look for aphid control alternatives.

Sprays of the TS2035 detergent at $0.5 \% \mathrm{v} / \mathrm{v}$, starting when the plants were approx. $40 \mathrm{~cm}$ tall until harvest, were effective in controlling $M$. donacis, with no toxicity to the plants, and with no significant differences when compared to the conventional insecticide imidacloprid. A high elimination of epicuticular wax was observed in the field and in the samples collected, which darkened the aphids when they were left without their characteristic whitish wax. This suggests that mortality of $M$. donacis occurred mainly by dehydration as a consequence of the removal of the epicuticle wax. This effect has also been observed in studies on mealybugs (Hemiptera), along with mortality by washing and removal of specimens from the plant (Curkovic and Araya, 2004; Burett, 2005).

Regarding those few individuals that remained attached to the leaves, observations under magnification revealed that some aphids moved erratically and/or did not move their legs, suggesting that their survival would be unlikely in the field.

Previous studies (Vincent et al., 2000) described the negative effect of imidacloprid, especially on ladybirds, such as larvae and adults of Harmonia axyridis (Pallas). Santos et al. (2017) and Schiess et al. (2017), verified its high toxicity for Hippodamia convergens (Guérin-Méneville), a coccinellid abundant on the plants in our study. As the populations of $M$. donacis did not affect yield and imidacloprid is toxic to the beneficial fauna (Mizell and Sconyers, 1992), its application is not advisable for the management of this aphid, and natural control should be considered. Additionally, some authors have indicated that, in case of crops destined for biomass, it is possible to increase the natural control of pests through the conservation of beneficial insects (Werling et al., 2011; Prasifka and Gray, 2012). Thus, the use of agricultural detergents would be the most viable option to protect natural enemies, since the detergents appear to be less toxic than a conventional insecticide, as observed by Ripa et al. (2006) in an assay to control the whitefly Aleurothrixus floccosus (Maskell) (Hemiptera: Aleyrodidae) and the red mite Panonychus citri (McGregor) (Acarina: Tetranychidae) on citrus.

Quantifying yield loss and economic damage is essential to establish an efficient pest control program. In energy crops these thresholds are expected to be higher than in conventional crops, since a low level of damage does not decrease the quality of the biomass, so energy crops should support higher pest densities (Fitt, 2011).

Angelini et al. (2005) stated that DM biomass production of giant reed is affected by harvest date, plant density, water supply, and fertilization. In our study, harvest of $A$. donax was conducted between the end of autumn and the beginning of winter to favor lower water content in the canes, obtaining a similar value $(\sim 56.2 \%)$ to those obtained in studies worldwide. For example, Angelini et al. (2005) reported that water content of the raw material was reduced $10 \%$ from autumn to winter, ranging between 52 and $58 \%$. Christou et al. (2003), on the other hand, harvested giant reed with $54 \%$ moisture.

Angelini et al. (2005; 2009) emphasized that production of the first year is the result of the biomass generated from individual rhizomes, and that plants growing at lower densities would have higher individual productions. In the following years, yield increases with plant density, until plant competition starts affecting yield. Angelini et al. (2009) obtained the highest yield of $A$. donax at densities of 20,000 plants ha ${ }^{-1}$.

For wild A. donax plants in California, Giessow et al. (2011) obtained $15.5 \mathrm{~kg} \mathrm{DM} \mathrm{m^{-2 }}$ and Spencer et al. (2006) reported $17.1 \mathrm{~kg} \mathrm{DM} \mathrm{m}^{-2}$ of aerial biomass. In trials established in Greece's temperate climate, annual yields from 15 to $39 \mathrm{t}$ $\mathrm{DM} \mathrm{ha}^{-1}$ have been sustained for several years, while Hidalgo and Fernández (2000) obtained a first year annual yield of $45.9 \mathrm{t} \mathrm{DM} \mathrm{ha}^{-1}$ in Spain. Angelini et al. (2009) reported yields of $30 \mathrm{t} \mathrm{DM} \mathrm{ha}^{-1}$ in Italy. Because of irrigation of the plots, DM yield reached higher values in our study. In plots treated with the TS2035 detergent, the greatest average yield obtained reached $95.1 \mathrm{t} \mathrm{ha}^{-1}$, followed by the treatment with imidacloprid with $88.8 \mathrm{t} \mathrm{ha}^{-1}$, and a mean yield of $84.1 \mathrm{t} \mathrm{ha}^{-1}$ in the untreated plots.

To some extent, the high yields obtained in our trial during the first year of growth of $A$. donax could be explained by the irrigation and fertilization of the crop. Applications of imidacloprid and TS2035 during the growing season kept the crop with low aphid populations through harvest. However, as $M$. donacis density did not significantly affect DM yields in the untreated control plots, control of $M$. donacis with insecticides would be unnecessary in bioenergy crops of $A$. donax infested with this aphid at the levels observed during this study. The DM yields obtained are considered promising for cultivating giant reed for energy purposes in the Mediterranean Region of Chile. However, as maximum yields of the crop are obtained on its $3^{\text {rd }}$ year (Christou et al., 2003), long-term evaluations are still needed. 


\section{CONCLUSIONS}

Control of $M$. donacis with insecticides would not be necessary in bioenergy crops of $A$. donax infested with $M$. donacis at the levels observed. However, long-term evaluations of DM yields are still needed.

\section{ACKNOWLEDGEMENTS}

This work was made possible by the funding from INNOVA-CHILE, Project BIOCOMSA 08CTE02-06, Desarrollo de Cultivos Energéticos.

\section{LITERATURE CITED}

Ahmad, R., P.-S. Liow, D.F. Spencer, and M. Jasieniuk. 2008. Molecular evidence for a single genetic clone of invasive Arundo donax in the United States. Aquatic Botany 88:113-120.

Angelini, L.G., L. Ceccarini, and E. Bonari. 2005. Biomass yield and energy balance of giant reed (Arundo donax L.) cropped in central Italy as related to different management practices. European Journal of Agronomy 22:375-389.

Angelini, L.G., L. Ceccarini, N. Nassi, and E. Bonari. 2009. Comparison of Arundo donax L. and Miscanthus x giganteus in a long-term field experiment in central Italy: Analysis of productive characteristics and energy balance. Biomass Bioenergy 33:635-643.

Bayer CropScience, 2014. Confidor ${ }^{\circledR} 350$ SC. Disponible en www.cropscience.bayer.cl/ soluciones/fichaproducto.asp?id=4 (Consulta 2 enero 2018).

Blackman, R.L., and V.F. Eastop. 2000. Aphids on the world's crops. 414 p. An identification and information guide. $2^{\text {nd }}$ ed. John Wiley \& Sons, Chichester, UK.

Bradshaw, J.D., J.R. Prasifka, K.L. Steffey, and M.E. Gray. 2010. First report of field populations of two potential aphid pests of the bioenergy crop Miscanthus $\times$ giganteus. Florida Entomologist 93(1):135-137.

Burett, G. 2005. Evaluación de dos detergentes agrícolas sobre ninfas de segundo estado y hembras de Pseudococcus longispinus (Targioni \& Tozzetti) en laboratorio. $56 \mathrm{p}$. Tesis Ing. Agrónomo. Facultad de Ciencias Agronómicas, Universidad de Chile, Santiago, Chile.

Casanova, M., W. Vera, W. Luzio, y O. Salazar. 2004. Edafología. Guía de clases prácticas. 75 p. Departamento de Ingeniería y Suelos, Facultad de Ciencias Agronómicas, Universidad de Chile, Santiago, Chile.
Christou, M., M. Mardikis, E. Alexopoulou, S.L. Cosentino, V. Copani, and E. Sanzone. 2003. Environmental studies on Arundo donax. p. 102-110. In Proc. $8^{\text {th }}$ International Conference on Environmental Science and Technology, Lemnos Island, Greece, 8-10 Sept. 2003. Curran Associates, Inc., New York, USA.

Curkovic, T., and J.E. Araya. 2004. Acaricidal action of two detergents against Panonychus ulmi (Koch) and Panonychus citri (McGregor) (Acarina: Tetranychidae) in the laboratory. Crop Protection 23(8):731-733.

El-Naggar, J.B., N. El-Hoda, and A. Zidan. 2013. Field evaluation of imidacloprid and thiamethoxam against sucking insects and their side effects on soil fauna. Journal of Plant Protection Research 53(4):375-387.

Fabre, V., C.A. Dedryver, J.L. Leterrier, and M. Plantegenest. 2003. Aphid abundance on cereals in autumn predicts yield losses caused by Barley yellow dwarf virus. Phytopathology 93(10):1217-1222.

Fitt, G.P. 2011. Critical issues in pest management for a future with sustainable biofuel cropping. Current Opinions in Environmental Sustainability 3:71-74.

Giessow, J.H., J. Casanova, R. Leclerc, R. MacArthur, G. Fleming, and J. Giessow. 2011. Arundo donax distribution and impact report. March 2011. Available at www. cal-ipc.org/wp-content/uploads/2017/11/ Arundo_Distribution_Impact_Report_CalIPC_March-2011_small.pdf (Accessed 3 April 2012).

Hidalgo, M., and J. Fernández. 2000. Biomass production of ten populations of giant reed (Arundo donax L.) under the environmental conditions of Madrid (Spain). p. 1881-1884. In Kyritsis, S., A.A.C. Beenackers, P. Helm, A. Grassi, and D. Chiaramonti (eds.). Biomass for Energy and Industry. Proceedings of the First World Conference. 5-9 June 2000, Vol. 1. Seville, Spain,. James \& James (Science Publishers), London, England.

Ingwell, L.L., R. Zemetra, C. Mallory-Smith, and N.A. Bosque-Pérez. 2014. Arundo donax infection with Barley yellow dwarf virus has implications for biofuel production and nonmanaged habitats. Biomass and Bioenergy 66:423-426.

Jeschke, P., R. Nauen, M. Schindler, and A. Elbert. 2011. Overview of the status and global strategy for neonicotinoids. Journal Agriculture \& Food Chemistry 59(7):28972908. 
Joshi, N.K., and V.K. Sharma. 2009. Efficacy of imidacloprid (Confidor 200 SL) against aphids infesting wheat crop. Journal of Central European Agriculture 10(3):217-222.

Lambert, A.M., T.L. Dudley, and K. Saltonstall. 2010. Ecology and impacts of the largestatured invasive grasses Arundo donax and Phragmites australis in North America. Invasive Plant Science Management 3:489494.

Lewandowski, I., J. Scurlock., E. Lindvall, and M. Christou. 2003. The development and current status of perennial rhizomatous grasses as energy crops in the US and Europe. Biomass and Bioenergy 25:335-361.

Mariani, C., R. Cabrini, A. Danin, P. Piffanelli, A. Fricano, S. Gomarasca, et al. 2010. Origin, diffusion and reproduction of the giant reed (Arundo donax L.): a promising weedy energy crop. Annals of Applied Biology 157(2):191202.

Michaud, J.P., and P.E. Sloderbeck. 2005. Russian wheat aphid. An introduced pest of small grains in the High Plains. 4 p. Kansas State University Agricultural Experiment Station and Cooperative Extension Service. Publication MF-2666. Hays, Kansas, USA.

Mizell, R.F., and M.C. Sconyers. 1992. Toxicity of imidacloprid to selected arthropod predators in the laboratory. Florida Entomologist 75(2):277-280.

Nassi o Di Nasso, N., N. Roncucci, F. Triana, C. Tozzini, and E. Bonari. 2011. Productivity of giant reed (Arundo donax L.) and miscanthus (Miscanthus x giganteus Greef et Deuter) as energy crops: Growth analysis. Italian Journal of Agronomy 6(e22):141-147. DOI:10.4081/ija.2011.e22

Nieto-Nafría, J.M., E. Fuentes-Contreras, M. Castro, M. Aldea, J. Ortego, y M. Pilar Mier Durante. 2016. Catálogo de los áfidos (Hemiptera, Aphididae) de Chile, con plantas hospedadoras y distribuciones regional y provincial. Graellsia (Museo Nacional de Ciencias Naturales, CSIC, Madrid, España) 72(2). Disponible en http://graellsia. revistas.csic.es/index.php/graellsia/article/ viewArticle/546/659 (Consulta 19 diciembre 2017).

Prasifka, J.R., and M.E. Gray. 2012. Research needs and potential effects of biomass crops on pest management. Journal of Integrated Pest Management 3(4):77-84.
Ripa, R., F. Rodríguez, P. Carral, y R. Luck. 2006. Evaluación de un detergente en base a benceno sulfonato de sodio para el control de la mosquita blanca Aleurothrixus floccosus (Maskell) (Hemiptera: Aleyrodidae) y de la arañita roja Panonychus citri (McGregor) (Acarina: Tetranychidae) en naranjos y mandarinos. Agricultura Técnica 66:115-123.

Santos, K.F.A., O. Zanuzo Zanardi, M.R. de Morais, C.R.O. Jacob, M.B. de Oliveira, and P.T. Yamamoto. 2017. The impact of six insecticides commonly used in control of agricultural pests on the generalist predator Hippodamia convergens (Coleoptera: Coccinellidae). Chemosphere 186:218-226.

Schiess, M., J.E. Araya, and T. Curkovic. 2017. Effect of an insecticide formulation on Hippodamia convergens (Guérin) and nymphs of Aphis craccivora (Koch) in the laboratory. Chilean Journal of Agriculture and Animal Science 33(2):136-141.

Spencer, D., P. Liowa, W.K. Chana, G. Ksander, and K. Getsinger. 2006. Estimating Arundo donax shoot biomass. Aquatic Botany 84:272276.

Tóth, E.K., E. Kriston, K. Nyerges, F. Nardin, M. Czakó, L. Márton, et al. 2011. Virological investigation of third-generation biomass plants -Arundo donax L. as an example. Available at www.cabdirect.org/cabdirect/ abstract/20123175720 (Accessed 3 April 2012).

Vincent, C., A. Ferrant, L. Guige, and J. Brun. 2000. Effects of imidacloprid on Harmonia axyridis (Coleoptera: Coccinellidae) larval biology and locomotory behavior. European Journal of Entomology 97:501-506.

Werling, B.P., T.D. Meehan, C. Gratton, and D.A. Landis. 2011. Influence of habitat and landscape perenniality on insect natural enemies in three candidate biofuel crops. Biological Control 59:304-312. 